\section{Rickets associated with anticonvulsant therapy in children with tuberous sclerosis}

Rickets (or osteomalacia) is well known to occur in patients taking long-term anticonvulsant therapy (Kruse, 1968; Dent et al., 1970; De Luca, Masotti, and Partington, 1972; Silver et al., 1974; Hahn et al., 1975; Borgstedt, et al., 1972) but the occurrence of this complication in tuberous sclerosis has been commented on only once (Borgstedt et al., 1972). This paper reports this occurrence in 5 children seen in the general paediatric unit of this hospital in the past 5 years.

\section{Case reports}

Case 1. A 15-year-old girl with severe mental retardation, a long history of seizures, marked adenoma sebaceum, and many cutaneous white macules was referred from the orthopaedic clinic, where she had attended with fractures of the left radius and scapula, right lateral malleolus, and both clavicles. Gross rickets and secondary hyperparathyroidism was shown radiographically (Fig. 1) and chemical analysis of plasma showed calcium $2 \cdot 18 \mathrm{mmol} / 1(8 \cdot 7 \mathrm{mg} / 100 \mathrm{ml})$, phosphate $1.02 \mathrm{mmol} / 1(3.1 \mathrm{mg} / 100 \mathrm{ml})$, alkaline phosphatase $1220 \mathrm{IU} / \mathrm{l}$. Plasma urea was $2 \cdot 2 \mathrm{mmol} / \mathrm{l}$ $(13 \mathrm{mg} / 100 \mathrm{ml}$ ) and there was a generalized aminoaciduria but no reducing substances in the urine. There was no clinical suggestion of intestinal malabsorption.

She had had infantile spasms with hypsarrhythmia between the ages of 5 and 10 months but was not treated at that time. The diagnosis of tuberous sclerosis had been made at the age of 4 years when she presented with generalized seizures and mental retardation, from which time she had taken primidone, ethosuximide and sulthiame subsequently having been added. Her diet had been normal, though she had never liked milk, and she had not been deprived of exposure to sunlight.

Treatment was begun with calciferol 10000 units daily, increasing after 3 months to 15000 units daily, and supplemental calcium (Calcium Sandoz 30-45 ml daily). There was gradual radiographic and biochemical (Fig. 2) improvement, though the plasma calcium was still low after 6 months of treatment.

Case 2. A 13-year-old boy with mental retardation, temporal lobe epilepsy, adenoma sebaceum, cutaneous neurofibromata, a shagreen patch, and intracranial calcification presented with infantile spasms at the age of 3 months, when he was treated with ACTH and phenobarbitone. He took phenobarbitone continuously to the age 12 years, when primidone was substituted because of his aggressive behaviour, for which he was also given diazepam and later thioridazine. There was no clinical evidence of rickets, but investigation showed plasma calcium $2.55 \mathrm{mmol} / 1(10 \mathrm{mg} / 100 \mathrm{ml})$, phosphate $1.82 \mathrm{mmol} / 1(5.6 \mathrm{mg} / 100 \mathrm{ml})$, and alkaline phosphatase $640 \mathrm{IU} / \mathrm{l}$; plasma 5-nucleotidase $5 \cdot 5$ IU/1. $X$-rays of pelvis, scapulae, wrists, and knees were normal. Treatment was started with calciferol 1000 units daily, and plasma alkaline phosphatase fell gradually to $317 \mathrm{IU} / 1$ over the next 3 months.

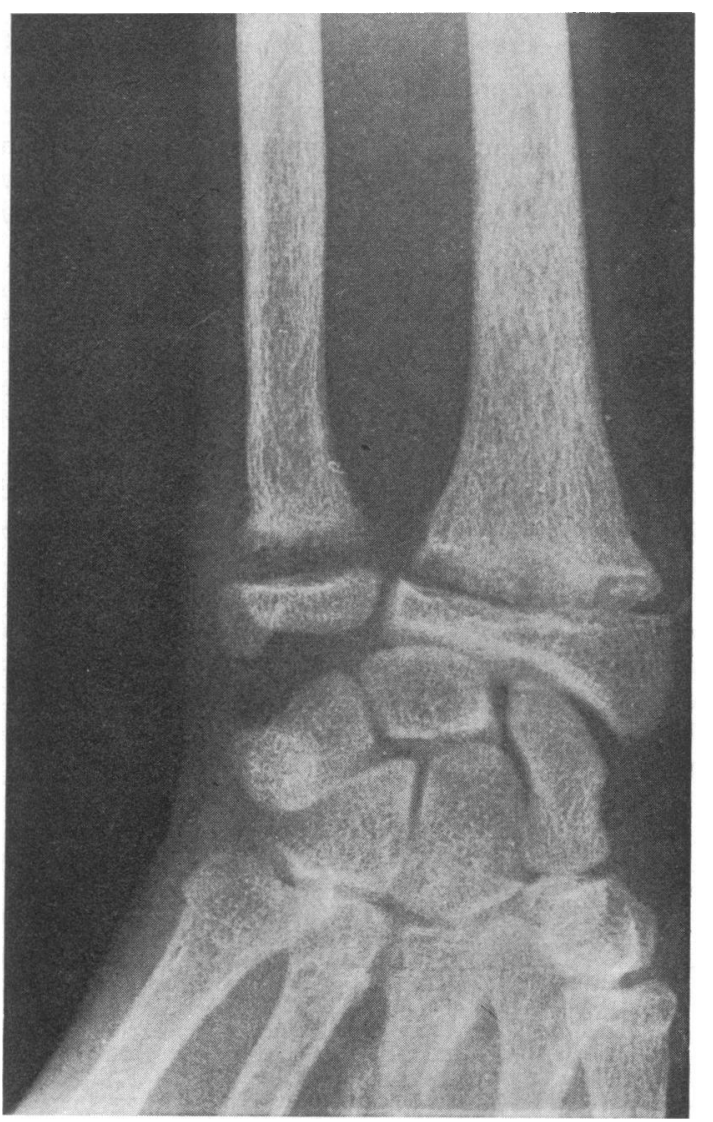

FIG. 1.-Case 1. X-ray of right wrist at time of presentation with rickets. There are also gross hyperparathyroid erosions, presumably secondary. 


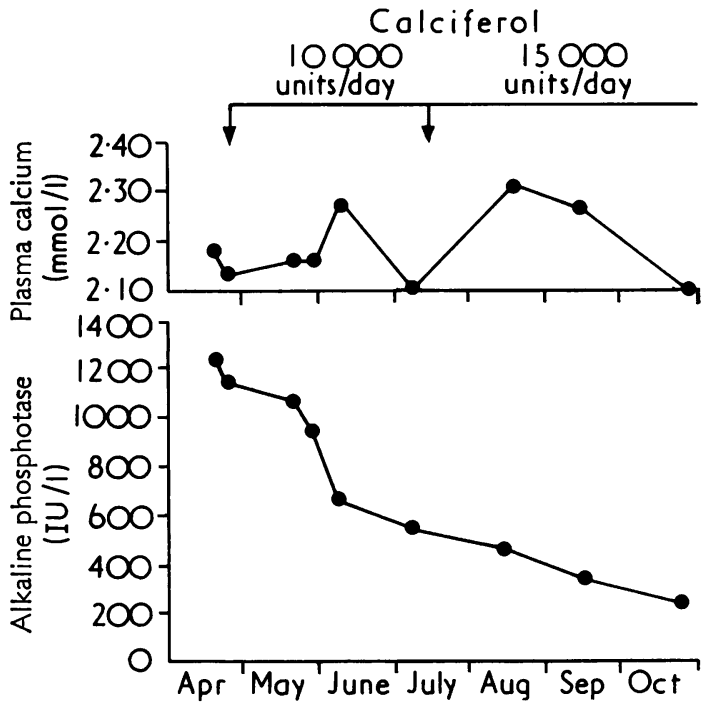

Fig. 2.-Case 1. Response to treatment.

Cases 3-5 (Table). All had undoubted tuberous sclerosis and clinically obvious rickets confirmed radiographically and biochemically. Cases 3 and 4 were brothers and both were thought to have taken a defective diet. Case 5 was a child of an Asian immigrant family. None had been institutionalized. All responded to calciferol in doses of either 3000 or 5000 units daily.

\section{Discussion}

Borgstedt et al. (1972) described 2 children with anticonvulsant associated rickets, one of whom suffered from tuberous sclerosis. They quoted Stögmann (1971) and a personal communication from Kruse (1972) as reporting tuberous sclerosis in 1 out of 4 and 2 out of 11 of their respective series of patients with rickets on anticonvulsant therapy. Dent et al. (1970) reported 4 cases of anticonvulsant drug osteomalacia, including one boy with intracranial calcification and an early history of infantile spasms who may have had tuberous sclerosis (A. Richens, personal communication, 1975). Of 5 patients studied by De Luca et al. (1972), one was shown at necropsy to have tuberous sclerosis, though the diagnosis had not been suspected during life (M. W. Partington, personal communication, 1976). Fischer, Fortune, and Gerritsen (1973) found high values of serum alkaline phosphatase in all of 7 patients with tuberous sclerosis. No details of treatment are given in their paper, but it seems likely that many of the children were taking long-term anticonvulsant therapy. In untreated children with tuberous sclerosis, Rundle, Fannin, and Bartlett (1967) reported low values of serum alkaline phsophatase.

It seems, therefore, that children with tuberous sclerosis may be particularly liable to develop rickets on anticonvulsant therapy. This liability most likely reflects the fact that many children with tuberous sclerosis need prolonged and intensive anticonvulsant therapy, though we are impressed that we have not seen this complication so frequently in other children who have had equally intensive and lengthy treatment. None of our patients had evidence of gastrointestinal or renal disease, but 2

TABLE

Details of 5 patients with tuberous sclerosis and rickets

\begin{tabular}{|c|c|c|c|c|c|c|}
\hline $\begin{array}{l}\text { Case } \\
\text { no. }\end{array}$ & $\begin{array}{c}\text { Age at } \\
\text { start of } \\
\text { anticonvulsant } \\
\text { therapy }\end{array}$ & $\begin{array}{l}\text { Age at } \\
\text { diagnosis } \\
\text { of rickets } \\
(y r)\end{array}$ & $\begin{array}{l}\text { Severity } \\
\text { of rickets }\end{array}$ & $\begin{array}{l}\text { Dose of } \\
\text { calciferol } \\
\text { (units/ } \\
\text { day) }\end{array}$ & $\begin{array}{l}\text { Anticonvulsant } \\
\text { treatment } \\
\text { at time of } \\
\text { rickets }\end{array}$ & $\begin{array}{l}\text { Other } \\
\text { anticonvulsant } \\
\text { treatment } \\
\text { given previously }\end{array}$ \\
\hline 1 & $4 \mathrm{yr}$ & 14 & +++ & 15000 & $\begin{array}{l}\text { Primidone, } \\
\text { sulthiame, } \\
\text { ethosuximide }\end{array}$ & \\
\hline 2 & $3 \mathrm{~m}$ & 13 & $\begin{array}{c}\uparrow \text { Alk phos } \\
\text { only }\end{array}$ & 1000 & $\begin{array}{l}\text { Primidone, } \\
\text { thioridazine }\end{array}$ & $\begin{array}{l}\text { Phenobarbitone, } \\
\text { diazepam }\end{array}$ \\
\hline 3 & $17 \mathrm{~m}$ & 3 & ++ & 3000 & $\begin{array}{l}\text { Phenytoin, } \\
\text { primidone, } \\
\text { carbamazepine }\end{array}$ & Phenobarbitone \\
\hline 4 & $6 \mathrm{~m}$ & 5 & ++ & 5000 & $\begin{array}{l}\text { Phenytoin, } \\
\text { primidone, } \\
\text { carbamazepine }\end{array}$ & Acetazolamide \\
\hline 5 & 3 yrs & 12 & ++ & 3000 & $\begin{array}{l}\text { Phenytoin, } \\
\text { phenobarbitone }\end{array}$ & $\begin{array}{l}\text { Phensuximide, } \\
\text { dexamphetamine, } \\
\text { acetazolamide, } \\
\text { sulthiame, } \\
\text { carbamazepine }\end{array}$ \\
\hline
\end{tabular}


(Cases 3 and 4) were thought to have had a deficient diet, and one (Case 5) was an Asian immigrant child and we see rickets frequently in this immigrant community. All of our patients were living at home and attending the outpatient clinic when they developed rickets.

The place of vitamin $\mathrm{D}$ prophylaxis for patients taking anticonvulsant therapy has been debated, but it seems reasonable to suggest that such prophylaxis may be particularly indicated in tuberous sclerosis. The amount of vitamin $\mathrm{D}$ required is uncertain, but is probably of the order of $500-1000$ units as a daily supplement to a normal diet (Hahn et al., 1975; Silver et al., 1974).

\section{Summary}

Five children with tuberous sclerosis and anticonvulsant-associated rickets have been seen in a general paediatric clinic over the last 5 years. It is suggested that vitamin $D$ prophylaxis is particularly indicated in patients with tuberous sclerosis taking anticonvulsant medication.

I thank Dr. J. S. Oldham for permission to publish details of Cases 3, 4, and 5.

\section{REFERENCES}

Borgstedt, A. D., Bryson, M. F., Young, L. W., and Forbes, G. B. (1972). Long-term administration of antiepileptic drugs and the development of rickets. Fournal of Pediatrics, 81, 9.

De Luca, K., Masotti, R. E., and Partington, M. W. (1972). Altered calcium metabolism due to anticonvulsant drugs. Developmental Medicine and Child Neurology, 14, 318.

Dent, C. E., Richens, A., Rowe, D. J. F., and Stamp. T. C. B. (1970). Osteomalacia with long-term anticonvulsant therapy in epilepsy. British Medical fournal, 4, 69.

Fischer, M. H., Fortune, J. S., and Gerritsen, T. (1973). Serum proteins and alkaline phosphatase levels in patients with tuberous sclerosis. American fournal of Mental Deficiency, 78, 674.

Hahn, T. J., Hendin, B. A., Scharp, C. R., Boisseau, V. C., and Haddad, J. G. (1975). Serum 25-hydroxycalciferol levels and bone mass in children on chronic anticonvulsant therapy. New England fournal of Medicine, 292, 550.

Kruse, R. (1968). Osteopathien bei antiepileptischer Langzeittherapie. Monatsschrift für Kinderheilkunde, 116, 378.

Rundle, A. T., Fannin, C. V., and Bartlett, K. (1967). Serum proteins and serum enzymes in tuberous sclerosis. Fournal of Mental Deficiency Research, 11, 85.

Silver, J., Davies, T. J., Kupersmitt, E., Orme, M., Petrie, A., and Vajda, F. (1974). Prevalence and treatment of vitamin D deficiency in children on anticonvulsant drugs. Archives of Disease in Childhood, 49, 344.

Stögmann, W. (1971). Ossifikationsstörungen bei antikonvulsiver Langzeitbehandlung. Paediatrie und Paedologie, 6, 280.

\section{P. ADDY}

Department of Paediatrics, Dudley Road Hospital, Birmingham B18 $7 Q H$.

\section{Motor nerve conduction velocity in spinal muscular atrophy of childhood}

Spinal muscular atrophy is a hereditary disease characterized by degeneration and loss of motor neurones in the spinal cord and brain stem. Three clinical forms are recognized. The severe infantile form of the disease usually has an early onset, either in utero or within the first 2-3 months, and death usually occurs within the first 2 years from severe respiratory involvement. The intermediate form is characterized by normal motor development up to the age of about 6 months, with the infants usually achieving the ability to sit, but unable thereafter to take weight on their legs or to stand and walk. In the mild form the children have normal milestones in the first year of life and are able to walk but show evidence of muscle weakness. Not all cases of spinal muscular atrophy fall neatly into these three categories; many borderline cases are also encountered.

The motor nerve conduction velocity is generally considered to be normal in diseases of anterior horn cells, including spinal muscular atrophy (Munsat et al., 1969; Hausmanowa-Petrusewicz, 1970). However, Gamstorp (1967) found borderline or slow nerve conduction velocities in 6 infants with spinal muscular atrophy, all severely affected. Buchthal and Olsen (1970) noted 'slightly decreased' peroneal nerve conduction velocities in 3 of 9 patients with infantile spinal muscular atrophy. In an extensive study of motor and sensory conduction velocities in Werdnig-Hoffmann disease, Raimbault and Laget (1972) found slow velocities for both motor and sensory fibres of ulnar and posterior tibial nerves in several of the patients. Hausmanowa-Petrusewicz et al. (1975) found motor nerve conduction velocities below normal in the ulnar, peroneal, and median nerve in 15, 7, and 3 cases of Werdnig-Hoffmann disease respectively.

This report describes the results of motor nerve conduction velocities in children with spinal muscular atrophy of different severity.

\section{Materials and methods}

This study comprises 29 children with spinal muscular atrophy in whom the diagnosis was subsequently confirmed by electromyography (EMG) and muscle biopsy. Their ages ranged from 3 months to 12 years. 12 were male and 17 female. For the purposes of this study they were placed into one of the following groups. (1) Severe (14 infants): this included all those infants with onset at birth or within 3-4 months of age, with severe paralysis and death usually within the first year. 